\title{
STUDI PERBANDINGAN TEPUNG TAPIOKA DENGAN TEPUNG TERIGU TERHADAP KARAKTERISTIK AMPLANG KERANG SIMPLING (Placuna placenta) YANG DIHASILKAN
}

\author{
Yuslinawati, S.TP ${ }^{(1)}$ dan Rifni Novitasari, S.TP., MP ${ }^{(2)}$ \\ (1)Alumni Teknologi Pangan Faperta UNISI \\ (2)Dosen Teknologi Pangan Faperta UNISI \\ rifninovi@gmail.com
}

\begin{abstract}
Abstrak
Telah dilakukan penelitian dilaboratorium Teknologi Pangan Fakultas Pertanian Universitas Islam Indragiri. Penelitian ini dilaksanakan 2 bulan yaitu dari bulan November sampaidenganDesember 2014. Analisa penelitian ini dilaksanakan di laboratorium Teknologi Pangan Fakultas Pertanian Universitas Andalas. Rancangan percobaan yang digunakan didalam penelitian ini adalah Rancangan Acak Lengkap (RAL) terdiri dari empat perlakuan yaitu: $\mathrm{A}=$ Tepung terigu $0 \%$ Tepung tapioka $100 \%, \mathrm{~B}=$ Tepung terigu 50\% Tepung tapioka 50\%, $\mathrm{C}=$ Tepung terigu $25 \%$ Tepung tapioka $75 \%, \mathrm{D}=$ Tepung terigu $100 \%$ Tepung tapioka $0 \%$. Perlakuan ini diulang sebanyak 3 kali sehingga diperoleh pula perlakuan 4 x 3 dengan jumlah 12 perlakuan. Data hasil pengamatan dianalisa menggunakan analisa keragaman (analysis of variance) pada taraf nyata 5\% bila terdapat berbeda nyata maka diujilanjut dengan beda nyata jujur (BNJ) pada taraf $5 \%$.

Hasil yang diperoleh menunjukan bahwa perbandingan tepung tapioka dan tepung terigu dalam pembuatan amplang memberikan pengaruh berbeda nyata terhadap kadar air, kadar protein, kadar lemak, dan uji organoleptik yang meliputi warna, rasa, tekstur,dan aroma. Hasil terbaik untuk standa rmutu berdasarkan komposisi kimia diperoleh dari perlakuan $\mathrm{C}$ (Tepung tapioka $75 \%$ dan tepung terigu $25 \%$ ) dengan hasil analisa kimia kadar air 8,27\%, kadar lemak 19,86\%, kadar protein $13,48 \%$,dengan skor uji organoleptik terhadap warna $2,11 \%$, rasa $2,21 \%$, aroma $2,08 \%$ dan tekstur $2,30 \%$.
\end{abstract}

Kata Kunci : Amplang, Tepung tapioka, Tepung terigu, dan Kerang simping (Placuna placenta)

\section{PENDAHULUAN}

Amplang merupakan jenis makanan ringan yang sangat populer diIndonesia, mengandung pati cukup tinggi, serta dibuat dari bahan dasar tepung tapioka. Amplang dapat dijadikan lauk makanan, karena rasanya yang gurih dan enak yang dapat menambah seleramakan (Rahmaniar dan Nurhayati, 2007 dalam Yusmeiarti, 2008). Ditinjau daribahan bakunya tepung tapioka dan dari bahan perasanya, banyak jenis kerupuk yang dapat dihasilkan seperti kerupuk ikan,kerupuk udang, kerupuk kedelai, kerupuk sari ayam dan lain-lain dengan variasibentuk kerupuk tergantung pada kreativitas pembuatnya (Yusmeiarti, 2008).

Kabupaten Indragiri Hilir kaya akan hasil perikanan yang bisa diolah 
menjadi bahan perasa untuk pembuatan kerupuk salah satunya adalah kerang simping (Placuna placenta). Tidak hanya cangkangnya yang dapat diolah menjadi bahan baku pembuatan biskuit yang mengandung kalsium (Putriet al, 2014) dan dagingnya dapat diolah berbagai macam olahan masakan bukan hanya untuk dikonsumsi sebagai lauk pauk, daging kerang simping (Placunaplacenta) juga dapat diolah sebagai bahan perasa pembuatan amplang.

Amplang adalah salah satu olahan makanan yang terbuat dari campuran tepung tapioka, bumbu rempah, perasa daging udang, daging ikan, telur, dandaging ayam, namun dengan inovasi terbaru penulis menggunakan daging kerang simping (Placuna placenta) sebagai bahan untuk menciptakan rasa amplang yang berbeda.

Hasnawati (2006), pada umumnya pembuatan amplang hanya menggunakan bahan dasar tepung tapioka saja. Dengan demikian belum diketahui hasil terbaik dari perbandingan tepung tapioka dengan tepung terigu dalam pembuatan amplang kerang simping (Placuna placenta). Berdasarkan permasalahan tersebut diatas maka penulis telah melakukan penelitian tentang "Studi Perbandingan Tepung Tapioka dengan Tepung Terigu Terhadapan Karakteristik Amplang Kerang Simping (Placuna placenta) yang Dihasilkan".

\section{Perumusan Masalah}

Amplang pada umumnya adalah makanan olahan berupa kerupuk yang terbuat dari campuran tepung tapioka dan campuran rempah-rempah dan dari hasil laut yaitu ikan, dan udang. Di Indragiri Hilir produk olahan amplang telah diolah dengan berbagai rasa namun pengolahan amplang yang menggunakan kerang simping (Placuna placenta) belum pernah dilakukan sehingga nilai jual dari kerang simping ini masih terbilang murah. Dengan demikian pemanfaatan daging kerang simping dalam pengolahan amplang sebagai pecipta rasa baru dengan menonjolkan sisi sumber daya alamyang ada di INHIL.

Pentingnya mengetahui konsentrasi tepung yang tepat dalam pembuatan amplang akan berpengaruh terhadap karakteristik amplang. Masalah utama dalam pengolahan amplang kerang simping (Placuna placenta) adalah belum diketahuinya perbandingan tepung tapioka dengan tepung terigu yang tepat untuk menghasilkan karakteristik amplang kerang simping (Placuna placenta) yang baik. Dengan demikian penulis telah melakukan penelitian dengan judul "Studi Perbandingan Tepung Tapioka Dengan Tepung Terigu Terhadap Karakteristik Amplang Kerang Simping (Placuna placenta) yang Dihasilkan".

\section{Tujuan Penelitian}

Tujuan penelitian ini adalah untuk mengetahui perlakuan terbaik kombimasi tepung tapioka dengan tepung terigu yang tepat terhadap karakteristik amplang kerang simping (Placuna placenta) yang dihasilkan.

\section{Manfaat Penelitian}

Hasil penelitian ini diharapkan dapat memberikan manfaat, sebagai sumber informasi pada pembuatan amplang dengan menggunakan kombinasi tepung tapioka dengan tepung terigu terhadap karakteristik amplang yang dihasilkan. 


\section{METODOLOGI PENELITIAN}

\section{Bahan dan Alat}

Bahan yang digunakan untuk pengolahan amplang kerang simping (Placuna placenta) adalah tepung tapioka, tepung terigu, daging kerang simping (Placuna placenta), bawang putih, telur, air, jeruk nipis, garam, monosodium glutamate (MSG), danminyak goreng. Adapun bahan yang digunakan untuk analisa kimia yaitu sampel, aquadest, Nitrogen Mikro Kjeldahl, $\quad \mathrm{K}_{2} \mathrm{SO}_{4}, \mathrm{HgO}, \quad \mathrm{H}_{2} \mathrm{SO}_{4}$ Pekat, $\mathrm{NaOH}-\mathrm{Na}_{2} \mathrm{~S}_{2} \mathrm{O}_{3}, \mathrm{H}_{3} \mathrm{BO}_{3}$, dan $\mathrm{HCl}$ $0,02 \mathrm{~N}$.

Sedangkan alat yang digunakan untuk pengolahan amplang kerang simping (Placuna placenta) adalah timbangan analitik, kompor, baskom, kuali, gunting, pisau, panci, sendok kuali, penyaringan, kipas angin dan talam. Adapun alat yang digunakan untuk analisa kimia yaitu cawan porselen, oven, desikator, penimbang, labu kjeldahl, labu semprot, gelas ukur, danalat destilasi, oven, labu lemak, kertas saring, alat destilasi, dan desikator.

\section{Metode Penelitian}

Rancangan

percobaanyang

digunakan didalam penelitian ini adalah

Rancangan Acak Lengkap (RAL) terdiri dari 4 (empat) perlakuan yaitu:

$\mathrm{A}=$ Tepung terigu $0 \%$ Tepung tapioka $100 \%$

$\mathrm{B}=$ Tepung terigu $50 \%$ Tepung tapioka $50 \%$

$\mathrm{C}=$ Tepung terigu $25 \%$ Tepung tapioka $75 \%$

$\mathrm{D}=$ Tepung terigu $100 \%$ Tepung tapioka $0 \%$

Perlakuan ini diulang sebanyak 3 kali sehingga diperoleh pula perlakuan 4 x 3 dengan jumlah 12 kali percobaan.
Data hasil pengamatan dianalisa menggunakan analisa keragaman (analysis of variance) pada taraf nyata $5 \%$ bila terdapat berbeda nyata maka diuji lanjut dengan beda nyata jujur (BNJ) pada taraf 5\% (Gaspersz, 1996).

$$
\mathrm{Y} i \mathrm{j}=\mu+\mathrm{pi}+\mathrm{Eij}
$$

Dimana:

Yij = Hasil pengamatan terhadap perbandingan tepung tapioka dan tepungterigu (1-3)

$\mu=$ Rata-rata populasi (1-3)

$\mathrm{Pi}=$ Pengaruh perbandingantepung tapioka dan tepung terigu (1-3)

Eij = Pengaruh sisa pada satuan percobaan yang mendapat perlakuan perbandingan tepung tapioka dan tepung terigu (1-3) pada ulangan (1-3)

$\mathrm{I}=$ Perlakuan perbandingan tepung tapioka dan tepung terigu (1-3)

$\mathbf{J}=$ Ulangan (1-3)

\section{Pelaksanaan Penelitian}

Tahap Pembuatan Amplang Kerang Simping (Hasnawati, 2006) yang Telah Dimodifikasi Oleh Penulis.

\begin{tabular}{lrlr}
\multicolumn{2}{c}{ Proses } & pembuatan & amplang \\
kerang & simping & (Placuna placenta) \\
hampir & sama & dengan pembuatan
\end{tabular} amplang pada umumnya yaitu meliputi proses pembersihan bahan baku, pencampuran bahan, pengadonan, pembentukan lembaran, pemotongan lembaran adonan, dan pengorengan, namun bedanya hanya pada penambahan tepung terigu pada pembuatan amplang kerang simping (Placuna placenta) ini.

1. Pembersihan

Pada proses pembersihanini bertujuan untuk membersihkan daging kerang simping dari cangkannya sehingga dapat di peroleh daging kerang simping yang bersih. Kemudian diberikan perasan 
jeruk nipis bertujuan untuk menghilangkan bau amis pada daging kerang simping.

2. Pengilingan

Proses pengilingan ini berfungsi untuk memperkecil ukuran partikel juga mengetraksi protein yang larut dan tidak larut dalam garam dan untuk memproses emolsi fisik kemampuan untuk mengekstraksi miosin lebih besar dari $\mathrm{pH}$ yang tinggi.

3. Pengadonan

Pengadonan dalam pengolahan amplang kerang simping (Placuna placenta) pada prinsipnya adalah pencampuran seluruh bahan yang telah disiapkan diantaranya tepung tapioka, tepung terigu, daging simping yang telah di halus, bawang putih yang telah dihalus, garam, dan penyedap rasa, telur, dicampurkan semua, diaduk sampai rata.

4. Pencetakan

Kemudian tuangkan diatas cetakkan (talam) dan ratakan menggunakan tangan selanjutnya, susun di atas kertas sambil dikeringkan menggunakan kipas angin. Potong adonan amplang yang telah kering menggunakan gunting dengan ketebalan $5 \mathrm{~mm}$ selanjutnya dikeringkan menggunakan kipas angin, bertujuan agar tidak terjadi kelengketan (penyatuan).
5. Pengorengan

Amplang kerang simping (Placuna placenta) mentah yang sudah dibentuk atau digunting, digoreng dalam minyak panas. Selama penggorengan terus diaduk-aduk dengan tujuan agar masaknya merata, penggorengan ini dilakukan selama $7-10$ menit pada suhu $100^{\circ} \mathrm{C}$ $120^{\circ} \mathrm{C}$. Setelah masak angkat menggunakan pengaduk dan penyaring. Penyaring ini berguna untuk memisahkan minyak yang masih tertinggal pada amplang kerang simping,selanjutnya dikumpulkan ke dalam keranjang yang telah di alasi kertas. Sebelum dikemas amplang kerang simping dimasukkan ke dalam stoples dan ditutup rapat gunanya untuk menghindari adanya kontaminasi. Ciri-ciri amplang kerang simping yang bagus hasil penggorengan adalah mengembang 2-3 kali saat digoreng dan memiliki cita rasa yang rata.

\section{HASIL DAN PEMBAHASAN}

\section{Kadar Air}

Kadar air adalah persentase kandungan air suatu bahan, yang dinyatakan berdasar berat basah atau berdasarkan berat kering (Syarief dan Halid, 1991). Hasil sidik ragam dari perbandingan tepung tapioka dengan tepung terigu dalam pembuatan amplang kerang simping (Placuna placenta) berbeda nyata pada taraf $5 \%$ terhadap parameter kadar air. Hal tersebut dapat dilihat pada Tabel 1 . 
Tabel 1. Rata-Rata Perbandingan Tepung Tapioka dengan Tepung Terigu Terhadap Kadar Air Amplang Kerang Simping (Placuna Placenta)

\begin{tabular}{|c|l|}
\hline \multicolumn{1}{|c|}{ Perlakuan } & Rata - rata (\%) \\
\hline A (Tepung Tapioka 100\% dan Tepung Terigu 0\%) & 4,55 a \\
B (Tepung Tapioka 50\% dan Tepung Terigu 50\%) & 7,08 a \\
C (Tepung Tapioka 75\% dan Tepung Terigu 25\%) & 8,27 a \\
D (Tepung Tapioka 0\% dan Tepung Terigu 100\%) & $11,00 \quad$ b \\
\hline
\end{tabular}

Keterangan : Angka-angka yang diikuti huruf yang sama berbeda tidak nyata menurut uji lanjut Tukey pada taraf 5\%.

Hasil analisa kadar air menunjukkan bahwa jumlah kadar air terendah terdapat pada perlakuan A (Tepung tapioka $100 \%$ dan tepung terigu $0 \%$ ) yaitu sebesar $4,55 \%$ dan tertinggi pada perlakuan D (Tepung tapioka 0\% dan tepung terigu $100 \%$ ) sebesar 11,00 $\%$. Hal ini disebabkan kadarair pada tepung tapioka (14\%) lebih rendah dari pada tepung terigu (15\%), penurunan kadar air pada amplang dan peningkatan kadar air pada amplang di karena pengaruh persentase tepung yang digunakan, namun demikian sifat tepung berfungsi sebagai pengikat yang mengikat daya kadar air, dimana tepung akan mengikat air yang berada dalam matriks daging simping sehingga kadar air pada daging simping semakin menurun dan penurunan ditentukan dengan jumlah persentase tepung yang ditambahkan. Hal ini sesuai dengan pernyataan Manullang et al. (1995) yang menyatakan penurunan kadar air akibat mekanisme interaksi pati dan protein sehingga air tidak dapat diikat secara sempurna karena ikatan hidrogen yang seharusnya mengikat air telah dipakai untuk interaksi pati dan protein. Dengan demikian semakin tinggi persentase tepung tapioka yang digunakan maka massa tepung tapioka dalam amplang akan semakin besar dan kadar air amplang akan semakin menurun.

Tepung terigu memiliki fraksi amilosa yang merupakan bagian dari pati yang dapat mengikat air pada amplang sehingga menyebabkan kenaikan kadar air pada amplang. Besarnya kadar air mengakibatkan lepasnya ikatan struktur protein, sehingga komponen protein terlarut dalam air. Hal ini dapat dilihat pada saat penambahan air selama proses yang mengakibatkan partikel pati membengkak dan kehilangan kekompakan ikatan yaitu sebagian dari amilosa berdifusi keluar disebabkan oleh pengaruh panas(Jenssen, 1993 cit oktavia, 2007).

Menurut SNI 2714.1:2009yaitu tentang kadar air pada kerupuk udang maksimum $12 \%$. Hasil ini menunjukkan bahwa kadar air amplang kerang simping (Placuna placenta) yang dihasilkan masih dalam batasan SNI.

\section{Kadar Protein}

Sudarmadji (1999) menyatakan kadar protein merupakan salah satu kelompok bahan nutrien, tidak seperti bahan makronirien lainnya (karbohidrat dan lemak) protein ini berperan lebih penting dalam pembentukan biomolekul dari pada sumber energi. Namun demikian apabila organism sedang kekurangan energi, maka protein ini dapat juga dipakai sebagai sumber energi. Keistimewaan lain dari protein adalah strukturnya yang selain mengandung $\mathrm{N}, \mathrm{C}, \mathrm{H}, \mathrm{O}$, kadang mengandung $\mathrm{S}, \mathrm{P}$, dan $\mathrm{Fe}$.

Hasil sidik ragam dari perbandingan tepung tapioka dengan tepung terigu dalam pembuatan amplang 
kerang simping (Placuna placenta) menunjukkan bahwa kadar protein $\mathrm{F}_{\text {hitung }}<\mathrm{F}_{\text {tabel }}$ pada taraf $5 \%$ berbeda nyata antara kadar protein tepung tapioka dengan tepung terigu terhadap parameter kadar protein. Analisa terhadap kadar protein amplang kerang simping (Placuna placenta) yang dilakukan pada masing-masing perlakuan, maka diperoleh hasil dapat dilihat pada table 2 .

Tabel 2. Rata-Rata Perbandingan Tepung Tapioka dengan Tepung Terigu Terhadap Kadar Protein Amplang Kerang Simping

\begin{tabular}{|c|c|}
\hline Perlakuan & \multicolumn{2}{|c|}{ Rata - rata (\%) } \\
\hline A (Tepung Tapioka 100\% dan Tepung Terigu 0\%) & 9,84 a \\
C (Tepung Tapioka 75\% dan Tepung Terigu 25\%) & 13,48 b \\
B (Tepung Tapioka 50\% dan Tepung Terigu 50\%) & $15,88 \quad$ c \\
D (Tepung Tapioka 0\% dan Tepung Terigu 100\%) & $20,09 \quad$ d \\
\hline
\end{tabular}

Keterangan : Angka-angka yang diikuti huruf yang sama berbeda tidak nyata menurut uji lanjut Tukey pada taraf 5\%.

Hasil analisa kadar protein menunjukkan bahwa jumlah kadar protein terendah pada perlakuan A (Tepung tapioka $100 \%$, tepung terigu $0 \%$ ) yaitu sebesar $9,84 \%$ dan kadar protein yang tertinggi pada perlakuan D (Tepung tapioka $0 \%$, tepung terigu $100 \%$ ) sebesar 20,09 \%. Hal ini dikarenakan kadar protein pada tepung tapioka (1,5\%) lebih rendah dibandingkan tepung terigu $(8,0 \%)$, dengan meningkat persentase tepung tapioka maka semakin menurunnya kadar protein dan semakin meningkatnya persentase tepung terigu maka semakin meningkatnya kadar protein pada amplang.

Protein yang ada di dalam tepung terigu yang tidak larut dalam air akan menyerap air dan ketika diaduk/diulen akan membentuk gluten yang akan menahan gas $\mathrm{CO}_{2}$ hasil pati di dalam tepung (Subarna, 1996 cit Rakhmah, 2012).

Menurut SNI (2009) yaitu tentang kadar protein pada kerupuk udang minimal $8 \%$. Hasil ini menunjukkan bahwa kadar protein amplang kerang simping (Placuna placenta) yang dihasilkan masih dalam batasan SNI.

\section{Kadar Lemak}

Menurut Djaenai

menyatakan kadar lemak merupakan ikatan organik yang terdiri atas unsurunsur karbon (C), hidogen $(\mathrm{H})$, dan oksigen $(\mathrm{O})$, yang mempunyai sifat dapat larut dalam zat-zat pelarut tertentu dalam pelarut lemak. Lemak yang memiliki titik lebur tinggi bersifat padat pada suhu kamar, sedangkan yang mempunyai titik lebur rendah bersifat cair.Lemak yang padat pada suhu kamar disebut lemak gaji sedangkan cair pada suhu kamar disebut minyak.

Hasil sidik ragam dari perbandingan tepung tapioka dengan tepung terigu dalam pembuatan amplang kerang simping (Placuna placenta) menunjukkan bahwa kadar lemakF $F_{\text {hitung }}<$ $F_{\text {tabel }}$ pada taraf $5 \%$ berbeda nyata antara kadar lemak tepung tapioka dengan tepung terigu terhadap parameter kadar lemak. Analisa terhadap kadar lemak amplang kerang simping (Placuna placenta) yang dilakukan pada masingmasing perlakuan, maka diperoleh hasil dapat dilihat pada table 3 . 
Tabel 3 . Rata-Rata Perbandingan Tepung Tapioka dengan Tepung Terigu Terhadap Kadar LemakAmplang Kerang Simping

\begin{tabular}{|c|c|}
\hline Perlakuan & \multicolumn{2}{|c|}{ Rata - rata (\%) } \\
\hline D (Tepung Tapioka 0\% dan Tepung Terigu100\%) & 13,57 a \\
B (Tepung Tapioka 50\% dan Tepung Terigu 50\%) & $18,81 \quad$ b \\
C (Tepung Tapioka 75\% dan Tepung Terigu 25\%) & $19,86 \quad$ b \\
A(Tepung Tapioka 100\% dan Tepung Terigu 0\%) & $24,17 \quad$ c \\
\hline
\end{tabular}

Keterangan : Angka-angka yang diikuti huruf yang sama berbeda tidak nyata menurut uji lanjut Tukey pada taraf 5\%.

Hasil analisa kadar lemak menunjukkan bahwa jumlah kadar lemak terendah pada perlakuan D (Tepung tapioka $0 \%$, Tepung terigu $100 \%$ ) yaitu sebesar 13,57 \% dan kadar lemak yang tertinggi pada perlakuan A (Tepung tapioka 100\%, Tepung terigu 0\%) sebesar 24,17 \%. Hal ini dikarenakan kadar lemak pada tepung tapioka $(0,10 \%)$ lebih rendah dibandingkan tepung terigu $(1,30 \%)$, dimana persentase perbandingan tepung tapioka tinggi,maka kadar lemak pada amplang semakin menurun. Menurut Sueparno (2003) bahwa kadar lemak produk olahan akan meningkat seiring dengan penambahan tepung. Dalam hal ini tepung terigu yang ditambahkan persentasenya lebih tinggi dengan kandungan lemak juga lebih tinggi dari tepung tapioka dengan demikina peningkatan persentase tepung terigu maka kadar lemak akan meningkat.

Menurut Depertemen Kesehatan RI (1996) yang menyatakan bahwa tepung tapioka terkandung lemak $0,1 \mathrm{~g} / 100 \mathrm{~g}$ bahan dan tepung terigu terkandung lemak $1,30 \mathrm{~g} / 100 \mathrm{~g}$ bahan. Dengan demikian semakin tinggi jumlah tepung terigu yang digunakan maka persentase kadar lemak akan tinggi dan semakin tinggi jumlah tepung tapioka yang ditambahkan maka kadar lemak yang terkandung pada amplang kerang simping akan rendah.

Menurut SNI (2009) yaitu tentang kadar lemak pada kerupuk udang maksimum 30,87 \%. Hasil ini menunjukkan bahwa kadar lemak amplang kerang simping (Placuna placenta) yang dihasilkan masih dalam batasan SNI.

\section{KESIMPULAN}

\section{Kesimpulan}

Berdasarkan hasil penelitian dapat disimpulkan bahwa perlakuan terbaik, terletak pada perlakuan C,dimana perlakuan $\mathrm{C}$ (Tepung tapioka $75 \%$ dan tepung terigu 25\%) dengan hasil analisa kimia kadar air 8,27\%, kadar lemak 19,86\%, kadar protein $13,48 \%$, dengan skor uji organoleptik terhadap warna $2,11 \%$, rasa $2,21 \%$, aroma $2,08 \%$ dan tekstur $2,03 \%$.

\section{Saran}

Disarankan pada penelitian selanjutnya daging kerang simping (Placuna placenta) yang akan dijadikan perlakuan guna mengetahui pengaruh daging kerang simping terhadap karakteristik produk serta dilakukan perlakuan pengemasan yang tepat untuk menjaga kualitas produk.

\section{DAFTAR PUSTAKA}

Amang, 1993. Mamfaat Minyak Goreng. https://www. facebook. com/ Minyak Kelapa Murni/posts. Diakses pada tanggal 13 Desember 2014 
AOAC Inc. New York Assosiation of Official Analytical Chermist (AOAC). 2005. Official Method of Analysis of The Association of Official Analytical of Chemist. Arlington : The Association of Official Analytical Chemist, inc.

Assosiation Of Official Analytical Chemist, 2005. Official Method Of Analysis of The Assosiation of Official Analytica of Chemist. Arlington : The Assosiantion Of Official Analystical Chemist, inc.

Astarini, 2010. Tanaman Jeruk Nipis .http://manfaat buah daun. blogspot. com/2013/11/manfaatjeruk-nipis-untuk-kesehatan. Html. Diakses pada tanggal 13 Desember 2014.

Astawan, M. 2008. Membuat Mie dan Bihun. Penebar Swadaya. Jakarta.

Ernawati, 2003. Kelebihan Tepung Tapioka.

Htt://www.pustaka.iptek.com.

Diakses pada tanggal 12 oktober 2013.

Hariana, 2006.Kandungan Kimia Jeruk Nipis.http://manfaatbuahdaun.blog spot. Com. manfaat-jeruk-nipisuntuk-kesehatan. Html. Diakses pada tanggal 5 juli 2014.

Hasnawati, 2006. Laporan magang. Pembuatan amplang udang. Tembilahan.

Muhammad., F. 2011. Chapter II.Universitas Sumatera Utara. Avalable: http://id.scribd.com/doc/54414512/ Chapter-II. (Diakses: 25 Januari 2013).

Ningsih, D. S., A. Apriantono., M. Puspitasari. 2010. Analisa Sensori Untuk Industri Pangan dan Agro.IPB Pres. Bogor.

Permatasari, S. S., Widyastuti dan Suciyati. 2009. Pengaruh Rasio
Tepung Talas dan Tepung Terigu

Terhadap Sifat Kimia dan Organoleptik Mie Basah. Prosiding Seminar Nasional FTP UNUD 2009.

Putri, Ayu Dewiani Yuharnanda, 2011. Makanan Ringan Ekstrudat. http://yuharnandha putri. Blog spot, com, Diakses pada tanggal 25 Mei 2013.

Setyawan, 1999. Sifat Kerupuk. htt://www.depkes.go.id. Diaksek pada taggal 08 agustus 2013.

Soepamo, 1992. Fungsi Garam. UGMPrees, Jakarta.

Soekarto, S.T.,1985. Penelitian Organoleptik. Pusat Pengembangan Teknologi Pangan. IPB,Bogor.

Sudarmadji. S, B. Haryono, dan Suhardi, 19984. Analisa Bahan Makanan dan Pertanian. Liberti, Yogyakarta.

Syarief, 1993. Bahan Pengemas Kerupuk. htt//www. Pustaka.Iptek.Com. Diakses Pada Tanggal 23 oktober 2014.

Widiani, R. 2012. Pengaruh Perbandingan Konsentrasi Tepung Terigu dengan Tapioka dan Sodium Tripoliphosphat dengan Sodium Bikarbonat Terhadap Karakteristik Kerupuk Pangsit.Skripsi. Jurusan Teknologi Pangan. Fakultas Teknik. Universitas Pasundan. Bandung.

Widyaningsih, T. B. dan E.S. Murtini. 2006. Alternatif Pengganti Formalin pada Produk Pangan. Trubus Agrisarana. Surabaya.

Winarno, 2002, Fungsi Monosodium Glutamat.http://moehs. wordpress.com. Diakses pada tangal 5 juli 2014.

Yudiati, 2002. Kandungan Gizi Kerang Simping (Placuna placenta). Jakarta : Gramedia. 